\title{
Nutrition Recommendations in Pregnancy and Lactation
}

\author{
Michelle A. Kominiarek, MD, MS [Associate Professor] \\ Department of Obstetrics and Gynecology, Division of Maternal-Fetal Medicine, Northwestern \\ University Feinberg School of Medicine, 250 East Superior Street, Suite 05-2175, Chicago, IL \\ 60611, (312)472-6747 \\ Priya Rajan, MD [Assistant Professor] \\ Department of Obstetrics and Gynecology, Division of Maternal-Fetal Medicine, Northwestern \\ University Feinberg School of Medicine, 250 East Superior Street, Suite 05-2175, Chicago, IL \\ 60611, (312) 472-4685 P, p-rajan@northwestern.edu
}

\section{Keywords \\ nutrition; pregnancy; lactation; gestational weight gain}

\section{Introduction}

Nutrition counseling is a cornerstone of prenatal care for all women during pregnancy. A woman's nutritional status not only influences her health, but also pregnancy outcomes and the health of her fetus-neonate. Physicians and other healthcare providers need to be cognizant of nutritional needs during pregnancy, as they differ significantly compared to non-pregnant populations. Furthermore, an individualized approach to nutritional counseling that considers a woman's access to food, socioeconomic status, race-ethnicity and cultural food choices, and body mass index (BMI) is recommended. In addition, many of the recommendations are geared for uncomplicated pregnancies, so adjustments need to be made when complications, such as gestational diabetes, arise. A nutritionist or registered dietitian can help facilitate dietary counseling and interventions. In this chapter, the maternal physiological adaptations as well as macronutrient and micronutrient requirements during pregnancy and lactation will be reviewed. Other discussions on these topics will include multiple gestations, obesity in pregnancy, pregnancies after bariatric surgery, special diets, and common exposures during pregnancy.

\footnotetext{
Corresponding author mkominia@nm.org.
}

Publisher's Disclaimer: This is a PDF file of an unedited manuscript that has been accepted for publication. As a service to our customers we are providing this early version of the manuscript. The manuscript will undergo copyediting, typesetting, and review of the resulting proof before it is published in its final citable form. Please note that during the production process errors may be discovered which could affect the content, and all legal disclaimers that apply to the journal pertain. 


\section{PREGNANCY}

\section{Energy Expenditure during Pregnancy}

Caloric intake should increase by approximately $300 \mathrm{kcal} /$ day during pregnancy. This value is derived from an estimate of $80,000 \mathrm{kcal}$ needed to support a full-term pregnancy and accounts not only for increased maternal and fetal metabolism but for fetal and placental growth. Dividing the gross energy cost by the mean pregnancy duration (250 days after the first month) yields the $300 \mathrm{kcal} /$ day estimate for the entire pregnancy. ${ }^{1,2}$ However, energy requirements are generally the same as non-pregnant women in the first trimester and then increase in the second trimester, estimated at $340 \mathrm{kcal}$ and $452 \mathrm{kcal}$ per day in the second and third trimesters, respectively. Furthermore, energy requirements vary significantly depending on a woman's age, BMI, and activity level. Caloric intake should therefore be individualized based on these factors.

\section{Laboratory Testing during Pregnancy}

Physiological changes during pregnancy alter the normal ranges of several laboratory values. Both total red blood cell mass and plasma volume increase, but plasma volume increases to a greater extent resulting in hemodilution and anemia during pregnancy. Consequently, a hemoglobin $<10.5 \mathrm{~g} / \mathrm{dl}$ or a hematocrit $<32 \%$ is considered anemic during the second trimester (Table 1). Serum total protein and albumin also decrease by approximately $30 \%$ compared to non-pregnant values. ${ }^{3}$ Additionally, because estrogen increases the hepatic production of certain proteins, there is greater protein binding of corticosteroids, sex steroids, thyroid hormones, and vitamin D during pregnancy, resulting in lower free levels.

\section{Nutrients}

Macronutrients-Recommended protein intake during pregnancy is $60 \mathrm{~g} / \mathrm{day}$, which represents an increase from $46 \mathrm{~g} / \mathrm{d}$ in non-pregnant states. In other words, this increase reflects a change to $1.1 \mathrm{~g}$ of protein $/ \mathrm{kg} /$ day during pregnancy from $0.8 \mathrm{~g}$ of protein $/ \mathrm{kg} / \mathrm{day}$ for non-pregnant states. ${ }^{2}$ Carbohydrates should comprise $45-64 \%$ of daily calories and this includes approximately 6-9 servings of whole grain daily. Total fat intake should comprise $20-35 \%$ of daily calories, similar to non-pregnant women.

Micronutrients-The recommendations for daily micronutrient intake for a pregnant woman are determined by the "Recommended Dietary Allowances" or RDA data. In general, these RDA refer to the levels of intake of essential nutrients that are judged by the Food and Nutrition Board of the Institute of Medicine (IOM) to be adequate to meet the known nutrient needs of practically all healthy persons. The RDA have been modified for pregnant women. Table 2 shows the dietary allowances for most vitamins and minerals during pregnancy and they are reviewed in further detail below.

A daily prenatal multivitamin is generally recommended before conception and during pregnancy. Table 3 describes the typical composition of a prenatal vitamin. The critical difference compared to other multivitamins is the folic acid dose, which is necessary to support rapid cell growth, cell replication, cell division, and nucleotide synthesis for fetal and placental development. While there is data to support additional folic acid and iron 
supplementation during pregnancy, there is no high quality evidence demonstrating that all women require the increased levels of nutrients in a prenatal vitamin.

Folic acid is the synthetic form of the naturally occurring B vitamin, folate. Folic acid is the form used in most vitamin supplements and food fortification. As mandated by the Food and Drug Administration, commonly fortified foods include bread, cereal, and pasta. Folate-rich food sources are citrus fruits, dark-green leafy vegetables, nuts, and liver. Folate requirements increase during pregnancy as a result of rapidly dividing cells related to fetal growth. Notably, folic acid supplements (400-800 $\mu$ g daily) taken prior to conception can reduce the risk for neural tube defects in the fetus. ${ }^{4}$ Since the FDA mandate, blood folate levels have increased and neural tube defects have declined. ${ }^{4}$ In order to reduce the risk for neural tube defects in their offspring, women are recommended to take folic acid from fortified food or supplements daily in addition to consuming a diet rich in food sources of folate. ${ }^{5}$ Women with a history of a neural tube defect in a prior pregnancy should take a higher dose (4mg) of folic acid daily for subsequent pregnancies. Deficiencies in folate have been associated with megaloblastic anemia in pregnancy, though not with other pregnancy outcomes such as preterm birth or stillbirths. ${ }^{6}$

Iron supplements have routinely been recommended in pregnancy because iron needs nearly double during pregnancy. A standard prenatal vitamin contains $27 \mathrm{mg}$ of elemental iron. Vitamin C supplements can assist with iron absorption, whereas milk and tea can inhibit iron supplementation. Women with iron deficiency, defined by a ferritin level $<15 \mu \mathrm{g} / \mathrm{L}$, can increase their hemoglobin by $2 \mathrm{~g} / \mathrm{dL}$ over a one month period with a daily replacement of 60-120 mg of elemental iron. Common side effects of iron, such as stomach pain, constipation, nausea, and vomiting are often reasons why women are not compliant with iron supplementation. Iron-rich foods include red meat, pork, fish, and eggs.

Vitamin D is a fat-soluble vitamin that is primarily found in fortified milk or juice; natural sources include eggs and fish such as salmon. The skin also manufactures vitamin D when it is exposed to sunlight. Regardless of the source - oral ingestion vs. skin absorption - further processing in the liver and then the kidney is required to create the active form, 1,25dihydroxyvitamin $\mathrm{D}$, which promotes calcium absorption from the intestines and thereby allows appropriate bone mineralization and growth. Vitamin D deficiency is common in pregnancy, especially in high-risk groups such as vegetarians, women who live in cold climates, and ethnic minority women with darker skin. Severe vitamin D deficiency has been associated with congenital rickets and fractures, but this is less common in the United States. While Vitamin D levels can be measured via a serum level of 25-hydroxy vitamin D, an optimal level during pregnancy has not been established. Furthermore, there is insufficient evidence to recommend screening all pregnant women for vitamin D deficiency. If vitamin D deficiency is discovered during pregnancy, then supplements (1000-2000 IU per day) can be given. ${ }^{7}$ In addition, routine vitamin $\mathrm{D}$ supplementation during pregnancy to prevent preeclampsia is also not recommended. ${ }^{8}$

Vitamin A is essential for cell differentiation and proliferation as well as development of the spine, heart, eyes, and ears. Offspring of mothers with vitamin A deficiency, which is rare in the United States, have a higher mortality rate, which may be associated with decreased 
immune function. Although most micronutrients have a wide safety margin with little concern for teratogenic effects, vitamin A is one exception. ${ }^{9}$ Excessive doses of Vitamin A (>10,000 IU/day) have been associated with cranial-facial (face, palate, ears) and cardiac birth defects. The maximal supplement in pregnancy is $8000 \mathrm{IU} /$ day. It is the retinol form of Vitamin A that is associated with teratogenic effects, not the carotenoid version found in food sources such as carrots.

Studies regarding the risks and benefits of fish during pregnancy can often seem contradictory. ${ }^{10}$ This is in part due to that that most fish contain competing benefits and risks in the forms of omega- 3 fatty acids and mercury. ${ }^{11,12}$ Omega-3 fatty acids are critical for fetal brain development and have been associated with improved vision in preterm infants, as well as better cardiovascular health later in life. ${ }^{13}$ Higher mercury levels in children, however, have been associated with deficits in memory, learning, and behavior. ${ }^{14}$ Ideally, pregnant women would consume those fish that are low in mercury and high in omega-3 fatty acids such as salmon, sardines, and anchovies.(Table 4) High mercury fish such as shark, swordfish, tilefish, and king mackerel should be avoided. The Federal Drug Administration (FDA) and the Environmental Protection Agency (EPA) websites offer information regarding local fish and their mercury content. ${ }^{15}$ Available data suggest that fish-oil supplements do not confer the same health benefits as consumption of the actual fish. ${ }^{16}$

\section{Gestational Weight Gain}

Pregnancy has traditionally been considered a time for weight gain, not weight loss. The obligatory weight gain during pregnancy is approximately $8 \mathrm{~kg}$ which accounts for the fetus, the placenta, amniotic fluid volume, and adaptations to maternal tissues (e.g., uterus, breast, blood volume). A weight gain less than this amount implies that existing maternal adipose and protein stores would be mobilized in order to support the pregnancy. Metabolic changes of women who lose weight during pregnancy are not well-described, but ketonemia, increased urinary nitrogen excretion, and decreased gluconeogenic amino acid production result after a period of fasting during pregnancy. ${ }^{17}$ Pregnancy is often considered a time of "accelerated starvation" due to the increase in insulin resistance, with an increased risk for developing ketonuria and ketonemia. ${ }^{18}$ This physiologic change is important to consider in the setting of weight loss during pregnancy because maternal ketonemia or ketonuria may subsequently be associated with abnormal fetal growth or later neurocognitive development. ${ }^{19-21}$

A woman's pre-pregnancy BMI determines the total amount of weight gain and rate of weight gain during pregnancy (Table 5). ${ }^{22}$ Of note, the gestational weight gain guidelines that IOM published in 2009 differ from their original 1990 recommendations in that women with a pre-pregnancy BMI $\geq 30 \mathrm{~kg} / \mathrm{m}^{2}$ should gain $5-9 \mathrm{~kg}$ or $11-20$ pounds during pregnancy. ${ }^{22,23}$ Women who are overweight or have obesity have lower ranges for recommended total gestational weight gain compared to normal-weight women, yet $>50 \%$ of all women exceed the gestational weight gain recommendations. ${ }^{24}$ The IOM 2009 guidelines also recommend that women should conceive at a normal weight so as to achieve optimal maternal and neonatal outcomes. ${ }^{22}$ One study found that women who gain weight in 
the appropriate range for their BMI during pregnancy have fewer adverse perinatal outcomes than those gaining above the described thresholds. ${ }^{25}$

\section{Special considerations}

Multiple gestations-In twins, the maternal metabolic rate is approximately $10 \%$ greater than in singletons. ${ }^{26}$

Furthermore, the physiological changes in a singleton pregnancy are exacerbated in multiple gestations. This includes an increase in plasma volume which results in further decreases in hemoglobin, albumin, and water soluble vitamins. ${ }^{27}$ There are no standardized nutritional guidelines for multiple gestations, but they have been inferred from singletons. One recommendation for macronutrient composition is $20 \%$ protein, $40 \%$ fat, and $40 \%$ carbohydrates. ${ }^{28,29}$ It is estimated that a $40 \%$ higher-calorie diet may maintain a woman's nutritional state during a twin pregnancy. Rates of iron deficiency anemia are 2.4-4 times higher in twins than in singletons. ${ }^{28}$ Anemia due to folate deficiency is 8 times more common in twins compared to singletons. ${ }^{27}$ As such, a $1 \mathrm{mg}$ folic acid daily supplement has been recommended for twin gestations. ${ }^{30}$ Some experts recommend 1000IU of vitamin D and $2000-2500 \mathrm{mg} / \mathrm{d}$ of calcium daily for twins. ${ }^{28}$ Multiple gestations have a higher risk of complications such as premature birth and low birth weight. The IOM 2009 guidelines for gestational weight gain in twin gestations are presented in Table 6. Of note, these guidelines are considered provisional, as the evidence to support them is not as strong as it is for singletons. Interestingly, a weight gain of 24 pounds by 24 weeks has been associated with higher rates of birth weights $>2500 \mathrm{~g} .{ }^{31,32}$ Evidence for nutritional management of higher order multiples (triplets, quadruplets, etc.) is lacking, but they can be managed similarly to twin gestations.

Obesity-The World Health Organization and the National Institutes of Health define normal weight as a BMI of $18.5-24.9 \mathrm{~kg} / \mathrm{m}^{2}$, overweight as a BMI of $25-29.9 \mathrm{~kg} / \mathrm{m}^{2}$, and obesity as a BMI of $30 \mathrm{~kg} / \mathrm{m}^{2}$ or greater. Obesity is further categorized by BMI into Class I $\left(30-34.9 \mathrm{~kg} / \mathrm{m}^{2}\right)$, Class II ( $\left.35-39.9 \mathrm{~kg} / \mathrm{m}^{2}\right)$, and Class III or extreme obesity ( $240 \mathrm{~kg} /$ $\left.\mathrm{m}^{2}\right) .{ }^{33,34}$ Trends in adult weight over the past couple of decades highlight the escalating role that obesity plays in women's health; $31.8 \%$ of reproductive age women (20-39 years) had obesity in 2011-2012. ${ }^{35}$ Women with a higher pre-pregnancy BMI have a greater risk for adverse perinatal outcomes. ${ }^{36,37}$ These include both maternal complications such as gestational diabetes, pregnancy-related hypertension, and cesarean deliveries along with adverse fetal effects such as birth defects, stillbirth, and abnormal fetal growth.(Table 7) As such, weight loss prior to pregnancy is strongly recommended in order to reduce the risk of these complications. ${ }^{38}$

Guidelines for the management of obesity during pregnancy differ among countries; those practices endorsed by the American Congress of Obstetricians and Gynecologists are listed below: 38

Gestational weight gain recommendations should be individualized by the BMI at the first prenatal visit and based on the IOM 2009 guidelines (11-20 pounds). 
- $\quad$ Early screening for glucose intolerance (gestational diabetes or overt diabetes) is recommended. If the initial early diabetes screening result is negative, a repeat diabetes screening generally is performed at 24-28 weeks of gestation.

Behavioral interventions employing changes to diet and exercise can improve postpartum weight reduction in contrast to exercise alone.

With respect to health behavior interventions, randomized and non-randomized studies of interventions to promote optimal gestational weight gain have emphasized combinations of dietary counseling, weight monitoring, and exercise programs. Although a few studies have shown a reduction in gestational weight gain for women with obesity after exposure to a health behavior intervention, the majority have found no benefit. For example, in one study in which women were randomized to a low glycemic index diet, the majority of women with obesity exceeded the gestational weight gain goals regardless of the study arm (57\% control vs. $60 \%$ intervention, $\mathrm{p}=0.8$ ). ${ }^{39}$ When the results of multiple studies have been examined cumulatively in meta-analyses, the interventions for women who are overweight or obese have been shown to have moderate or no influence at all on gestational weight gain or other perinatal outcomes. ${ }^{40-44}$ Further research is indicated to determine how to promote adherence to gestational weight gain guidelines with health behavior interventions. Another concern is the influence maternal obesity has on childhood weight, resulting in a propagation of the cycle of obesity. It is likely that environmental and epigenetic influences and not just genetic mechanisms play a role in the obesity epidemic. Several theories suggest that in utero nutrition may impact chronic diseases such as diabetes, hypertension, and other metabolic diseases later in life in the offspring. ${ }^{45,46}$ As this research continues to evolve, clinicians should consider that maternal nutrition during pregnancy may have life-long consequences for the offspring.

\section{Pregnancy after bariatric surgery}

Pregnancy after bariatric surgery is not uncommon as fertility often improves after a bariatric surgery procedure. ${ }^{47-49}$ Given that bariatric procedures can create deficiencies of micro- and macronutrients, a pregnancy occurring after a bariatric surgery procedure requires particular attention to nutritional status. As stated previously, requirements for calories, vitamins, and minerals increase during pregnancy, so nutritional deficiencies in the bariatric surgery patient can be exacerbated during pregnancy. The most common deficiencies that occur after bariatric surgery are vitamin $B_{12}$, folate, and iron. ${ }^{50}$ Because malabsorptive procedures (e.g., Roux-en-y gastric bypass [RYGB], biliopancreatic diversion) have a higher risk for nutritional deficiencies, closer surveillance in pregnancies that occur after these types of surgeries is appropriate.$^{51}$ However, derangements in nutrients can also occur after restrictive-type procedures (e.g., laparoscopic adjustable gastric banding), so it may be reasonable to screen all women who are pregnant post-bariatric surgery for nutritional deficiencies. ${ }^{52}$ Guidelines for screening and management of nutritional deficiencies during pregnancy are adapted from those designed for non-pregnant states and include laboratory testing once a trimester or every 3 months if the levels are normal (Table 8). ${ }^{53,54}$ Iron deficiency anemia is frequently a long-term complication of bariatric surgery, occurring in $6 \%$ to $50 \%$ of patients after RYGB ${ }^{55-58}$ In pregnancies after 
bariatric surgery, iron deficiency anemia can be diagnosed in the usual manner with a low mean corpuscular volume, and abnormal iron studies (e.g., low serum iron, high total ironbinding capacity, and a low serum ferritin) keeping in mind the physiologic anemia that occurs during pregnancy (Table 1). Treatment of vitamin and mineral deficiencies during pregnancy, in terms of dose and duration, is similar to that of non-pregnant states.

\section{Eating disorders}

For women with either a history of or current eating disorder (e.g., anorexia nervosa, bulimia), additional questions regarding their weight should be asked including how they feel about weight gain, being weighed at every prenatal visit (which is customary in prenatal care practices in the United States), and the ongoing changes in their body. ${ }^{59}$ With respect to weighing, a woman's preference about weighing (i.e., whether or not she prefers to see the numbers) should be assessed and documented in the chart. Counseling on gestational weight gain goals is still important for these women as weight influences the growth and development of the fetus. Similar to management prior to pregnancy, a collaborative team of experts in eating disorders should continue to manage and treat these women during the pregnancy.

\section{Vegetarians}

There are varying types of vegetarian diets such as ovolactovegetarian (includes dairy and egg products), ovovegetarian (includes eggs), lactovegetarian (includes dairy products), and vegan (excludes eggs, dairy, and any other animal products). Alternative protein sources for these women include beans, peas, soy, nuts, nut butter, and milk and egg products. Minerals that may be deficient in their diets include iron, calcium, zinc, and vitamin $\mathrm{B}_{12}$. Laboratory testing for these specific nutrients may be indicated.

\section{Common Exposures}

Historically, pregnant women were advised to abstain from caffeine. However, those earlier studies that demonstrated an increased risk of adverse obstetric outcomes such as miscarriage, poor fetal growth, and stillbirth were subject to substantial bias ${ }^{60}$ Additionally, the risk of those outcomes occurring generally increased with fairly substantive doses of caffeine, such as greater than 4 cups of coffee a day. ${ }^{61,62}$ Most current research suggests that smaller amounts of caffeine intake, less than 200-300mg daily, are not associated with increased perinatal risk.

It is particularly important that general food safety precautions such as ensuring meat and dairy-containing foods are appropriately refrigerated are followed during pregnancy because pregnant women are more susceptible to the effects of infections from certain microorganisms. Ensuring foods are pasteurized and/or appropriately cooked can lower the risk of acquiring infections such as Listeria and Toxoplasmosis. Listerial infections are associated with increased risk for pregnancy complications such as preterm delivery and stillbirth. ${ }^{63}$ Toxoplasmosis infections can result in ventriculomegaly and other fetal-neonatal complications. ${ }^{64}$ Wearing gloves when gardening may also reduce the risk of exposure to toxoplasmosis. ${ }^{65}$ 
While current recommendations from professional organizations do not recommend universal screening for lead exposure, risk assessment should be performed at the first prenatal visit and testing of lead levels performed if any risk factors are identified. High lead levels have been associated with a greater risk of obstetric complications such as miscarriage, poor fetal growth, and neurodevelopmental impairment. ${ }^{66}$

\section{LACTATION}

\section{Physiology and Production}

Breastfeeding and breast milk are the global standard for infant feeding. The World Health Organization, the U.S. Surgeon General, the American Academy of Pediatrics, the American Congress of Obstetricians and Gynecologists, the American Academy of Family Practice, and the Academy of Breastfeeding Medicine all support this statement. The American Academy of Pediatrics further recommends exclusive breastfeeding for the first 6 months and breastfeeding at least through the first year of life. ${ }^{67}$ Similar to pregnancy, energy and nutritional requirements also differ during lactation and breastfeeding.

Women who breastfeed require approximately 500 additional $\mathrm{kcal} /$ day beyond what is recommended for non-pregnant women. ${ }^{68}$ The estimate is derived from the mean volume of breast milk produced per day (mean $780 \mathrm{~mL}$, range $450-1200 \mathrm{~mL}$ ) and the energy content of milk $(67 \mathrm{kcal} / 100 \mathrm{~mL}) .{ }^{69}$ During pregnancy, most women store an extra 2 to $5 \mathrm{~kg}(19,000$ to $48,000 \mathrm{kcal})$ in tissue, mainly as fat, in physiologic preparation for lactation. If women do not consume the extra calories, then body stores are used to maintain lactation. It is not unusual for lactating women to lose $0.5-1.0 \mathrm{~kg} /$ month after the first postpartum month. ${ }^{70}$

There are even less evidence-based recommendations for nutrient intake during breastfeeding compared to pregnancy. Lactation is considered successful when the breast-fed infant is gaining an appropriate amount of weight. The recommended daily allowance for protein during lactation is an additional $25 \mathrm{~g} / \mathrm{day}$. Requirements of many micronutrients increase compared to pregnancy, with the exception of vitamins D and K, calcium, fluoride, magnesium, and phosphorus. As such, it is recommended that women to continue to take a prenatal vitamin daily while they are breastfeeding (Tables 2,3). Weight loss during lactation does not usually impact the quantity or quality of breast milk, but maternal deficiencies in magnesium, vitamin $\mathrm{B}_{6}$, folate, calcium, and zinc have been described during lactation. ${ }^{69,71}$ Both fat (vitamins A, D, K) and water-soluble vitamins (vitamins C, $\mathrm{B}_{1}, \mathrm{~B}_{6}, \mathrm{~B}_{12}$, and folate) are secreted into breast milk and their levels are reduced in breast milk when there is a maternal vitamin deficiency. ${ }^{72-74}$ Fortunately, these vitamin deficiencies in breast milk respond to maternal supplementation. On the other hand, calcium, phosphorus, and magnesium levels in breast milk are independent of maternal serum levels and diet. ${ }^{75}$ Maternal factors such as stress, anxiety, and smoking can decrease milk production, but the quantitative and caloric value of breast milk does not change with dieting and exercise. ${ }^{76-83}$ Moreover, a woman's weight, BMI, body fat percentage, and weight gain during pregnancy do not influence milk production. ${ }^{84-86}$ 


\section{Special Considerations}

Multiple Gestations-Approximately $40-90 \%$ of mothers of twins initiate breastfeeding. ${ }^{87}$ The production of milk is primarily determined by infant demand rather than the maternal capacity to lactate. As such, for women attempting to breastfeed twins and triplets, the supply will meet the demand. Continuation of micronutrient supplementations given antenatally in the form of a prenatal vitamin is appropriate for women who are breastfeeding twins. Twins can breastfeed either simultaneously or separately.

Obesity-Several studies have demonstrated that women with obesity have decreased rates of initiating breastfeeding and breastfeed for shorter durations compared to normal weight women. ${ }^{88}$ Biological (i.e. delayed lactation), psychological (i.e., embarrassment related to body size and difficulty in breastfeeding discreetly), mechanical (i.e., larger breasts and nipples that create difficulties with latching), and medical (i.e., cesarean deliveries, diabetes, thyroid dysfunction) factors have been theorized to explain these findings, but the exact etiology is likely a combination of factors. To combat this trend and increase the likelihood that women with obesity attain their breastfeeding goals, they need additional support and encouragement to breastfeed, including assistance with appropriate latching techniques and demonstration of appropriate infant positions, to aid with initiation and continuation of lactation.

Bariatric surgery-Women who have had bariatric surgery are also advised to follow the recommendation of breastfeeding for at least 6 months. Laboratory evaluation of micronutrient levels, as described in Table 8 for pregnant women, is also recommended for breastfeeding women after bariatric surgery, with one group suggesting they be tested as frequently as every 3 months. ${ }^{89}$ The infant's provider also should be aware of the mother's history of bariatric surgery as well as any of her specific dietary restrictions or identified nutrient deficiencies. For women who have a gastric banding procedure, one recommendation is to keep the band deflated until the successful establishment of breastfeeding. ${ }^{90}$ Though few studies have evaluated the nutritional content of breast milk produced by lactating women after bariatric surgery, it is likely similar to other women. While infants who are born to women with obesity have a higher rate of early childhood obesity, this may be offset by the reduced risk of early childhood obesity in infants who are predominantly breastfed..$^{91-93}$

Vegetarians-Recommended dietary guidelines for vegetarians during lactation are lacking. Vitamin D supplements are recommended for women who do not drink milk or other food fortified with vitamin D. A vitamin $\mathrm{B}_{12}$ supplement $(2.6 \mu \mathrm{g} / \mathrm{d})$ is also recommended for women who consume ovolactovegetarian and vegan diets. ${ }^{94}$ Another recommendation is to consume $1200-1500 \mathrm{mg} /$ day of calcium because of the possible decreased intake and absorption from a plant-based diet. ${ }^{95}$ The FDA recommends similar precautions regarding avoiding higher mercury fish during lactation. Adverse neonatal effects have not been demonstrated with ordinary maternal fish consumption during breastfeeding. 


\section{ONLINE RESOURCES FOR CLINICIANS}

www.phenxtoolkit.org Screening questions to identify nutritional issues or deficiencies in patients.

http://resources.iom.edu/Pregnancy/WhatToGain.html?

_ga $=1.247807815 .195235449 .1445895119$ BMI calculator

http://fnic.nal.usda.gov/interactiveDRL. Calculators for daily energy needs and interactive dietary reference intakes for healthcare professionals

http://www.choosemyplate.gov/supertracker-tools/daily-food-plans/moms.html Allows health care professionals to estimate energy and nutrient requirements during pregnancy and lactation

www.marchofdimes.com/pregnancy/nutrition_indepth.html Resource for general prenatal dietary guidelines from the March of Dimes

http://iom.nationalacademies.org/Activities/Children/PregnancyWeightDissemination/2013SEP-09/ /media/Files/About\%20the\%20IOM/Pregnancy-Weight/ProvidersBro-Final.pdf? _ga $=1.148168439 .195235449 .1445895119$ Review on how to implement the IOM gestational weight gain guidelines

http://iom.nationalacademies.org/Activities/Children/PregnancyWeightDissemination/2013SEP-09/ToolKit.aspx Webinar that reviews a toolkit on implementing the IOM gestational weight gain guidelines

http://iom.nationalacademies.org/Activities/Children/PregnancyWeightDissemination/2013SEP-09/ /media/Files/About\%20the\%20IOM/Pregnancy-Weight/ IOMPregnancyMythsFactsEnglish.pdf Myths for providers to dispel during the course of prenatal care

http://www.foodsafety.gov/risk/pregnant/chklist_pregnancy.html Checklist of foods to avoid during pregnancy

http://www.fda.gov/food/foodborneillnesscontaminants/metals/ucm393070.htm Resource from the FDA on fish consumption during pregnancy

https://www.breastfeeding.asn.au/bf-info/common-concerns\%E2\%80\%93mum/ dietBreastfeeding information and nutrition

Summary and Future Considerations-Nutrition counseling is a cornerstone of prenatal care for all women during pregnancy and it also extends to lactation. Clinicians should be aware of the physiological adaptations that occur during pregnancy and lactation and how these changes influence the nutritional needs of pregnant and lactating women. One area of research that would assist providers and women in meeting their nutritional requirements and gestational weight gain goals is the measurement of diet and physical activity that is specific to pregnancy. Effective interventions that target health behaviors are 
also needed to improve a woman's nutritional status and assist her in meeting the gestational weight gain goals.

\section{Acknowledgments}

This work was supported by the Eunice Kennedy Shriver National Institute of Child Health \& Human Development of the National Institutes of Health under Award Number K23HD076010 (MAK).

\section{References}

1. Forsum E, Lof M. Energy metabolism during human pregnancy. Annu Rev Nutr. 2007; 27:277-292. [PubMed: 17465854]

2. Trumbo, P.; Yates, AA.; Poos, M. Food and Nutrition Board, Institute of Medicine: Dietary Reference Intakes for Energy, Carbo-hydrate, Fiber, Fat, Fatty Acids, Cholesterol, Protein, and Amino Acids. National Academies Press; Washington, DC: 2002. SS

3. Hytten, F. Clinical Physiology in Obstetrics. Blackwell Scientific Publications; Oxford: 1991. CG

4. Pitkin RM. Folate and neural tube defects. Am J Clin Nutr. 2007; 85(1):285S-288S. [PubMed: 17209211]

5. Otten, JJ.; Meyers, LD. Dietary reference intakes. The essential guide to nutrient requirements. National Academies Press; 2006. HJP

6. Lassi ZS, Salam RA, Haider BA, Bhutta ZA. Folic acid supplementation during pregnancy for maternal health and pregnancy outcomes. Cochrane Database Syst Rev. 2013; 3:CD006896.

7. Siega-Riz, AM.; Mehta, U. Clincial Updates in Women's Health Care. In: Artal, R., editor. Nutrition. Vol. 13. American College of Obstetricians and Gynecologists; Washington, D.C.: 2014.

8. Practice ACoO. ACOG Committee Opinion No. 495: Vitamin D: Screening and supplementation during pregnancy. Obstetrics and gynecology. 2011; 118(1):197-198. [PubMed: 21691184]

9. Humphrey JH, West KP Jr. Sommer A. Vitamin A deficiency and attributable mortality among under-5-year-olds. Bull World Health Organ. 1992; 70(2):225-232. [PubMed: 1600583]

10. Wenstrom KD. The FDA's new advice on fish: it's complicated. American journal of obstetrics and gynecology. 2014; 211(5):475-478. e471. [PubMed: 25072735]

11. Myers GJ, Davidson PW, Cox C, et al. Prenatal methylmercury exposure from ocean fish consumption in the Seychelles child development study. Lancet. 2003; 361(9370):1686-1692. [PubMed: 12767734]

12. Hibbeln JR, Davis JM, Steer C, et al. Maternal seafood consumption in pregnancy and neurodevelopmental outcomes in childhood (ALSPAC study): an observational cohort study. Lancet. 2007; 369(9561):578-585. [PubMed: 17307104]

13. Genuis SJ, Schwalfenberg GK. Time for an oil check: the role of essential omega-3 fatty acids in maternal and pediatric health. Journal of perinatology : official journal of the California Perinatal Association. 2006; 26(6):359-365. [PubMed: 16688204]

14. Grandjean P, Weihe P, White RF, et al. Cognitive deficit in 7-year-old children with prenatal exposure to methylmercury. Neurotoxicology and teratology. 1997; 19(6):417-428. [PubMed: 9392777]

15. Administration USFaD. Fish: What Pregnant Women and Parents Should Know. 2015. http:// www.fda.gov/Food/FoodborneIllnessContaminants/Metals/ucm393070.htm 2014. Accessed October 15

16. Makrides M, Gibson RA, McPhee AJ, Yelland L, Quinlivan J, Ryan P. Effect of DHA supplementation during pregnancy on maternal depression and neurodevelopment of young children: a randomized controlled trial. JAMA : the journal of the American Medical Association. 2010; 304(15):1675-1683. [PubMed: 20959577]

17. Felig P. Maternal and fetal fuel homeostasis in human pregnancy. Am J Clin Nutr. 1973; 26(9): 998-1005. [PubMed: 4600999]

18. Freinkel N. Banting Lecture 1980. Of pregnancy and progeny. Diabetes. 1980; 29(12):1023-1035. [PubMed: 7002669] 
19. Stehbens JA, Baker GL, Kitchell M. Outcome at ages 1, 3, and 5 years of children born to diabetic women. Am J Obstet Gynecol. 1977; 127(4):408-413. [PubMed: 835641]

20. Rizzo T, Metzger BE, Burns WJ, Burns K. Correlations between antepartum maternal metabolism and child intelligence. N Engl J Med. 1991; 325(13):911-916. [PubMed: 1881416]

21. Silverman BL, Rizzo T, Green OC, et al. Long-term prospective evaluation of offspring of diabetic mothers. Diabetes. 1991; 40(Suppl 2):121-125. [PubMed: 1748240]

22. Institute of Medicine. Weight gain during pregnancy: reexamining the guidelines. Washington, DC: 2009.

23. Nutrition during pregnancy. Institute of Medicine; Washington, DC: 1990.

24. Deputy NP, Sharma AJ, Kim SY. Gestational Weight Gain - United States, 2012 and 2013. MMWR Morb Mortal Wkly Rep. 2015; 64(43):1215-1220. [PubMed: 26540367]

25. Johnson J, Clifton RG, Roberts JM, et al. Pregnancy outcomes with weight gain above or below the 2009 Institute of Medicine guidelines. Obstetrics and gynecology. 2013; 121(5):969-975. [PubMed: 23635732]

26. Casele HL, Dooley SL, Metzger BE. Metabolic response to meal eating and extended overnight fast in twin gestation. Am J Obstet Gynecol. 1996; 175(4):917-921. Pt 1. [PubMed: 8885748]

27. Rosello-Soberon ME, Fuentes-Chaparro L, Casanueva E. Twin pregnancies: eating for three? Maternal nutrition update. Nutr Rev. 2005; 63(9):295-302. [PubMed: 16220640]

28. Goodnight W, Newman R, Society of Maternal-Fetal M. Optimal nutrition for improved twin pregnancy outcome. Obstetrics and gynecology. 2009; 114(5):1121-1134. [PubMed: 20168116]

29. Luke B. Nutrition in multiple gestations. Clin Perinatol. 2005; 32(2):403-429. vii. [PubMed: 15922790]

30. Young BC, Wylie BJ. Effects of twin gestation on maternal morbidity. Seminars in perinatology. 2012; 36(3):162-168. [PubMed: 22713496]

31. Luke B, Gillespie B, Min SJ, Avni M, Witter FR, O'Sullivan MJ. Critical periods of maternal weight gain: effect on twin birth weight. Am J Obstet Gynecol. 1997; 177(5):1055-1062. [PubMed: 9396893]

32. Luke B, Minogue J, Witter FR, Keith LG, Johnson TR. The ideal twin pregnancy: patterns of weight gain, discordancy, and length of gestation. Am J Obstet Gynecol. 1993; 169(3):588-597. [PubMed: 8372868]

33. Health NIo. The Practical Guide: Identification, Evaluation, and Treatment of Overweight and Obesity in Adults; Paper presented at: NIH Publication No. 98-40832000;

34. Obesity: preventing and managing the global epidemic. Report of a WHO consultation. World Health Organ Tech Rep Ser. 2000; 894:i-xii. 1-253. [PubMed: 11234459]

35. Ogden CL, Carroll MD, Kit BK, Flegal KM. Prevalence of childhood and adult obesity in the United States, 2011-2012. JAMA. 2014; 311(8):806-814. [PubMed: 24570244]

36. Hauger MS, Gibbons L, Vik T, Belizan JM. Prepregnancy weight status and the risk of adverse pregnancy outcome. Acta Obstet Gynecol Scand. 2008; 87(9):953-959. [PubMed: 18720038]

37. Cnattingius S, Bergstrom R, Lipworth L, Kramer MS. Prepregnancy weight and the risk of adverse pregnancy outcomes. N Engl J Med. 1998; 338(3):147-152. [PubMed: 9428815]

38. Obstetrics and gynecology. 2015; 126(6):e112-126. [PubMed: 26595582]

39. Walsh JM, McGowan CA, Mahony R, Foley ME, McAuliffe FM. Low glycaemic index diet in pregnancy to prevent macrosomia (ROLO study): randomised control trial. BMJ. 2012; 345:e5605. [PubMed: 22936795]

40. Dodd JM, Grivell RM, Crowther Ca, Robinson JS. Antenatal interventions for overweight or obese pregnant women: a systematic review of randomised trials. BJOG : an international journal of obstetrics and gynaecology. 2010; 117:1316-1326. [PubMed: 20353459]

41. Campbell F, Johnson M, Messina J, Guillaume L, Goyder E. Behavioural interventions for weight management in pregnancy: a systematic review of quantitative and qualitative data. BMC Public Health. 2011; 11:491. [PubMed: 21696589]

42. Tanentsapf I, Heitmann BL, Adegboye AR. Systematic review of clinical trials on dietary interventions to prevent excessive weight gain during pregnancy among normal weight, overweight and obese women. BMC pregnancy and childbirth. 2011; 11:81. [PubMed: 22029725] 
43. Oteng-Ntim E, Varma R, Croker H, Poston L, Doyle P. Lifestyle interventions for overweight and obese pregnant women to improve pregnancy outcome: systematic review and meta-analysis. BMC Med. 2012; 10:47. [PubMed: 22574949]

44. Thangaratinam S, Rogozinska E, Jolly K, et al. Effects of interventions in pregnancy on maternal weight and obstetric outcomes: meta-analysis of randomised evidence. BMJ. 2012; 344:e2088. [PubMed: 22596383]

45. Barker DJ, Osmond C, Kajantie E, Eriksson JG. Growth and chronic disease: findings in the Helsinki Birth Cohort. Ann Hum Biol. 2009; 36(5):445-458. [PubMed: 19562567]

46. Barker DJ. The developmental origins of adult disease. European journal of epidemiology. 2003; 18(8):733-736. [PubMed: 12974544]

47. Paulen ME, Zapata LB, Cansino C, Curtis KM, Jamieson DJ. Contraceptive use among women with a history of bariatric surgery: a systematic review. Contraception. 2010; 82(1):86-94. [PubMed: 20682146]

48. Teitelman M, Grotegut CA, Williams NN, Lewis JD. The impact of bariatric surgery on menstrual patterns. Obes Surg. 2006; 16(11):1457-1463. [PubMed: 17132411]

49. Gosman GG, King WC, Schrope B, et al. Reproductive health of women electing bariatric surgery. Fertil Steril. 2010; 94(4):1426-1431. [PubMed: 19815190]

50. Shankar P, Boylan M, Sriram K. Micronutrient deficiencies after bariatric surgery. Nutrition. 2010; 26(11-12):1031-1037. [PubMed: 20363593]

51. Mechanick JI, Youdim A, Jones DB, et al. Clinical practice guidelines for the perioperative nutritional, metabolic, and nonsurgical support of the bariatric surgery patient-2013 update: Cosponsored by american association of clinical endocrinologists, The obesity society, and american society for metabolic \& bariatric surgery*. Obesity (Silver Spring). 2013; 21(Suppl 1):S1-S27. [PubMed: 23529939]

52. Gudzune KA, Huizinga MM, Chang HY, Asamoah V, Gadgil M, Clark JM. Screening and Diagnosis of Micronutrient Deficiencies Before and After Bariatric Surgery. Obesity surgery. 2013

53. Bariatric surgery and pregnancy. Practice Bulletin \#105; Gynecologists ACoOa; 2009.

54. Mechanick JI, Youdim A, Jones DB, et al. Clinical practice guidelines for the perioperative nutritional, metabolic, and nonsurgical support of the bariatric surgery patient--2013 update: cosponsored by American Association of Clinical Endocrinologists, The Obesity Society, and American Society for Metabolic \& Bariatric Surgery. Obesity (Silver Spring). 2013; 21(Suppl 1):S1-27. [PubMed: 23529939]

55. Simon SR, Zemel R, Betancourt S, Zidar BL. Hematologic complications of gastric bypass for morbid obesity. South Med J. 1989; 82(9):1108-1110. [PubMed: 2772679]

56. Heber D, Greenway FL, Kaplan LM, et al. Endocrine and nutritional management of the postbariatric surgery patient: an Endocrine Society Clinical Practice Guideline. The Journal of clinical endocrinology and metabolism. 2010; 95(11):4823-4843. [PubMed: 21051578]

57. Alvarez-Cordero R, Aragon-Viruette E. Post-operative Complications in a Series of Gastric Bypass Patients. Obes Surg. 1992; 2(1):87-89. [PubMed: 10765170]

58. Halverson JD. Micronutrient deficiencies after gastric bypass for morbid obesity. Am Surg. 1986; 52(11):594-598. [PubMed: 3777703]

59. American Psychiatric A. Treatment of patients with eating disorders,third edition. American Psychiatric Association. Am J Psychiatry. 2006; 163(7 Suppl):4-54. [PubMed: 16925191]

60. Bracken MB. Potential confounding still clouds the possible association of maternal caffeine intake and low birth weight. Evidence-based medicine. 2015; 20(1):37. [PubMed: 25525041]

61. Maternal caffeine intake during pregnancy and risk of fetal growth restriction: a large prospective observational study. BMJ. 2008; 337:a2332. [PubMed: 18981029]

62. Bech BH, Nohr EA, Vaeth M, Henriksen TB, Olsen J. Coffee and fetal death: a cohort study with prospective data. American journal of epidemiology. 2005; 162(10):983-990. [PubMed: 16207803]

63. Obstetrics and gynecology. 2014; 124(6):1241-1244. [PubMed: 25411758]

64. Neu N, Duchon J, Zachariah P. TORCH infections. Clinics in perinatology. 2015; 42(1):77-103. viii. [PubMed: 25677998] 
65. Prevention CfDCa. Parasites - Toxoplasmosis. 2015. http://www.cdc.gov/parasites/toxoplasmosis/ prevent.html 2013. Accessed October 15

66. Obstetrics and gynecology. 2012; 120(2):416-420. Pt 1. [PubMed: 22825110]

67. Pediatrics. 2012; 129(3):e827-841. [PubMed: 22371471]

68. Guidelines for perinatal care. 7th. American Academy of Pediatrics and the American College of Obstetricians and Gynecologists; Washington, DC: 2012.

69. Nutrition during lactation. Institute of Medicine, National Academy Press; Washington, DC: 1991.

70. Weekly SJ. Diets and eating disorders: implications for the breastfeeding mother. NAACOG's clinical issues in perinatal and women's health nursing. 1992; 3(4):695-700.

71. Gartner LM, Greer FR, Section on B, Committee on Nutrition. American Academy of P. Prevention of rickets and vitamin D deficiency: new guidelines for vitamin D intake. Pediatrics. 2003; 111(4):908-910. Pt 1. [PubMed: 12671133]

72. Butte NF, Calloway DH. Evaluation of lactational performance of Navajo women. Am J Clin Nutr. 1981; 34(10):2210-2215. [PubMed: 7293949]

73. Hollis, B.; Lambert, PW.; Horst, RL. Factors affecting the antirachitic sterol content of native milk. In: Holick, MF.; Anast, CS., editors. Perinatal Calcium and Phosphorous Metabolism. Elsevier Science Publishers BV; Amsterdam: 1983. p. 157GT

74. von Kries R, Shearer M, McCarthy PT, Haug M, Harzer G, Gobel U. Vitamin K1 content of maternal milk: influence of the stage of lactation, lipid composition, and vitamin K1 supplements given to the mother. Pediatr Res. 1987; 22(5):513-517. [PubMed: 3684378]

75. Prentice A. Calcium supplementation during breast-feeding. N Engl J Med. 1997; 337(8):558-559. [PubMed: 9262501]

76. Schanler RJ, Hurst NM. Human milk for the hospitalized preterm infant. Seminars in perinatology. 1994; 18(6):476-484. [PubMed: 7701350]

77. Hopkinson JM, Schanler RJ, Fraley JK, Garza C. Milk production by mothers of premature infants: influence of cigarette smoking. Pediatrics. 1992; 90(6):934-938. [PubMed: 1437437]

78. Vio F, Salazar G, Infante C. Smoking during pregnancy and lactation and its effects on breast-milk volume. Am J Clin Nutr. 1991; 54(6):1011-1016. [PubMed: 1957815]

79. Andersen AN, Lund-Andersen C, Larsen JF, et al. Suppressed prolactin but normal neurophysin levels in cigarette smoking breast-feeding women. Clin Endocrinol (Oxf). 1982; 17(4):363-368. [PubMed: 7139967]

80. Dewey KG. Effects of maternal caloric restriction and exercise during lactation. J Nutr. 1998; 128(2 Suppl):386S-389S. [PubMed: 9478032]

81. Dewey KG, Lovelady CA, Nommsen-Rivers LA, McCrory MA, Lonnerdal B. A randomized study of the effects of aerobic exercise by lactating women on breast-milk volume and composition. $\mathrm{N}$ Engl J Med. 1994; 330(7):449-453. [PubMed: 8289849]

82. Dusdieker LB, Hemingway DL, Stumbo PJ. Is milk production impaired by dieting during lactation? Am J Clin Nutr. 1994; 59(4):833-840. [PubMed: 8147327]

83. McCrory MA, Nommsen-Rivers LA, Mole PA, Lonnerdal B, Dewey KG. Randomized trial of the short-term effects of dieting compared with dieting plus aerobic exercise on lactation performance. Am J Clin Nutr. 1999; 69(5):959-967. [PubMed: 10232637]

84. Dewey KG, Heinig MJ, Nommsen LA, Lonnerdal B. Maternal versus infant factors related to breast milk intake and residual milk volume: the DARLING study. Pediatrics. 1991; 87(6):829837. [PubMed: 2034486]

85. Butte NF, Garza C, Stuff JE, Smith EO, Nichols BL. Effect of maternal diet and body composition on lactational performance. Am J Clin Nutr. 1984; 39(2):296-306. [PubMed: 6695830]

86. Michaelsen KF. Nutrition and growth during infancy. The Copenhagen Cohort Study. Acta Paediatr Suppl. 1997; 420:1-36. [PubMed: 9185902]

87. Flidel-Rimon O, Shinwell ES. Breast feeding twins and high multiples. Arch Dis Child Fetal Neonatal Ed. 2006; 91(5):F377-380. [PubMed: 16923939]

88. Wojcicki JM. Maternal prepregnancy body mass index and initiation and duration of breastfeeding: a review of the literature. J Womens Health (Larchmt). 2011; 20(3):341-347. [PubMed: 21434834] 
89. Kaska L, Abacjew-Chmylko A, et al. Nutrition and Pregnancy after bariatric surgery. ISRN Obesity. 2013; 2013:6. KJ.

90. Dixon JB, Dixon ME, O'Brien PE. Pregnancy after Lap-Band surgery: management of the band to achieve healthy weight outcomes. Obesity surgery. 2001; 11(1):59-65. [PubMed: 11361170]

91. Arenz S, Ruckerl R, Koletzko B, von Kries R. Breast-feeding and childhood obesity--a systematic review. Int J Obes Relat Metab Disord. 2004; 28(10):1247-1256. [PubMed: 15314625]

92. Owen CG, Martin RM, Whincup PH, Smith GD, Cook DG. Effect of infant feeding on the risk of obesity across the life course: a quantitative review of published evidence. Pediatrics. 2005; 115(5):1367-1377. [PubMed: 15867049]

93. Ip S, Chung M, Raman G, et al. Breastfeeding and maternal and infant health outcomes in developed countries. Evid Rep Technol Assess (Full Rep). 2007; (153):1-186.

94. Picciano MF. Pregnancy and lactation: physiological adjustments, nutritional requirements and the role of dietary supplements. The Journal of nutrition. 2003; 133(6):1997S-2002S. [PubMed: 12771353]

95. Venti CA, Johnston CS. Modified food guide pyramid for lactovegetarians and vegans. The Journal of nutrition. 2002; 132(5):1050-1054. [PubMed: 11983836] 


\section{Key points}

1. Energy, macronutrient, and micronutrient requirements increase during both pregnancy and lactation.

2. Gestational weight gain goals vary according to the pre-pregnancy body mass index. Women who meet the weight gain goals have improved perinatal outcomes.

3. Special attention is required in the nutritional management of multiple gestations, obesity, and pregnancies after bariatric surgery. 


\section{Synopsis}

The nutritional status of a woman during pregnancy and lactation is not only critical for her health, but for future generations. While a nutritionist or registered dietitian can help facilitate dietary counseling and interventions, physicians also need to be cognizant of nutritional needs during pregnancy, as they differ significantly compared to non-pregnant populations. Furthermore, an individualized approach to nutritional counseling that considers a woman's nutritional status and body mass index is recommended. 


\section{Table 1}

Definitions of anemia during pregnancy

\begin{tabular}{|l|l|l|}
\hline Trimester & Hemoglobin (g/dl) & Hematocrit (\%) \\
\hline First & $<11.0$ & $<33$ \\
\hline Second & $<10.5$ & $<32$ \\
\hline Third & $<11.0$ & $<33$ \\
\hline $\begin{array}{l}\text { Normal values for non- } \\
\text { pregnant women }\end{array}$ & 12.1 to 15.1 & $37-48 \%$ \\
\hline
\end{tabular}




\section{Table 2}

Recommended daily dietary allowances for pregnant and lactating women

\begin{tabular}{|l|l|l|l|}
\hline Nutrient & Non-Pregnant & Pregnant $^{*}$ & Lactation $^{*}$ \\
\hline Vitamin A $(\mu \mathrm{g} / \mathrm{d})$ & 700 & 770 & 1300 \\
\hline Vitamin D $(\mu \mathrm{g} / \mathrm{d})$ & 5 & 15 & 15 \\
\hline Vitamin E $(\mathrm{mg} / \mathrm{d})$ & 15 & 15 & 19 \\
\hline Vitamin $\mathrm{K}(\mu \mathrm{g} / \mathrm{d})$ & 90 & 90 & 90 \\
\hline Folate $(\mu \mathrm{g} / \mathrm{d})$ & 400 & 600 & 500 \\
\hline Niacin $(\mathrm{mg} / \mathrm{d})$ & 14 & 18 & 17 \\
\hline Riboflavin $(\mathrm{mg} / \mathrm{d})$ & 1.1 & 1.4 & 1.6 \\
\hline Thiamin $(\mathrm{mg} / \mathrm{d})$ & 1.1 & 1.4 & 1.4 \\
\hline Vitamin $\mathrm{B}_{6}(\mathrm{mg} / \mathrm{d})$ & 1.3 & 1.9 & 2 \\
\hline Vitamin $\mathrm{B}_{12}(\mu \mathrm{g} / \mathrm{d})$ & 2.4 & 2.6 & 2.8 \\
\hline Vitamin $\mathrm{C}(\mathrm{mg} / \mathrm{d})$ & 75 & 85 & 120 \\
\hline Calcium $(\mathrm{mg} / \mathrm{d})$ & 1,000 & 1,000 & 1,000 \\
\hline Iron $(\mathrm{mg} / \mathrm{d})$ & 18 & 27 & 9 \\
\hline Phosphorus $(\mathrm{mg} / \mathrm{d})$ & 700 & 700 & 700 \\
\hline Selenium $(\mu \mathrm{g} / \mathrm{d})$ & 55 & 60 & 70 \\
\hline Zinc $(\mathrm{mg} / \mathrm{d})$ & 8 & 11 & 12 \\
\hline
\end{tabular}

Data from Otten JJ, Pitzi Hellwig J, Meyers LD, Editors. Dietary reference intakes. The essential guide to nutrient requirements. Washington, DC: National Academies Press; 2006.

Applies to women $>18$ years old 
Table 3

Typical composition of micronutrients in a prenatal vitamin

\begin{tabular}{|l|l|l|}
\hline Component & Amount & $\begin{array}{l}\text { \% Daily Value for Pregnant } \\
\text { and Lactating Women }\end{array}$ \\
\hline Vitamin A & $4,000 \mathrm{IU}$ as beta carotene & $50 \%$ \\
\hline Vitamin $\mathrm{D}_{3}$ & $400 \mathrm{IU}$ as Cholecalciferol & $100 \%$ \\
\hline Vitamin $\mathrm{E}$ & $11 \mathrm{IU}$ as dl-Alpha Tocopheryl acetate & $37 \%$ \\
\hline Folic acid & $800 \mathrm{\mu g}$ & $100 \%$ \\
\hline Niacin & $18 \mathrm{mg}$ as niacinamide & $90 \%$ \\
\hline Riboflavin & $1.7 \mathrm{mg}$ as thiamin mononitrate & $85 \%$ \\
\hline Thiamin & $1.5 \mathrm{mg}$ & $88 \%$ \\
\hline Vitamin $\mathrm{B}_{6}$ & $2.6 \mathrm{mg}$ as pyridoxine hydrochloride & $104 \%$ \\
\hline Vitamin $\mathrm{B}_{12}$ & $4 \mu \mathrm{g}$ as cyanocobalamin & $50 \%$ \\
\hline Vitamin $\mathrm{C}$ & $100 \mathrm{mg}$ as ascorbic acid & $167 \%$ \\
\hline Calcium & $150 \mathrm{mg}$ as calcium carbonate & $12 \%$ \\
\hline Iron & $27 \mathrm{mg}$ as ferrous fumarate & $150 \%$ \\
\hline Zinc & $25 \mathrm{mg}$ as zinc oxide & $167 \%$ \\
\hline
\end{tabular}




\section{Table 4}

Fish to Avoid During Pregnancy and Lactation

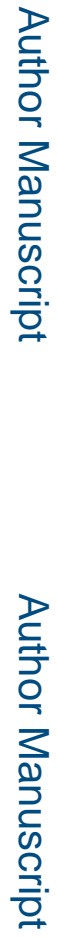

Shark
Swordfish
Tilefish
King Mackerel




\section{Table 5}

Gestational weight gain recommendations

\begin{tabular}{|c|c|c|}
\hline $\begin{array}{l}\text { Pre-pregnancy } \\
\text { BMI }\end{array}$ & $\begin{array}{l}\text { Total weight } \\
\text { gain at term }\end{array}$ & $\begin{array}{l}\text { Rate of weight gain in the } 2^{\text {nd }} \text { and } 3^{\text {rd }} \\
\text { trimester; Mean (range) }\end{array}$ \\
\hline $\begin{array}{l}\text { Underweight } \\
\left(<18.5 \mathrm{~kg} / \mathrm{m}^{2}\right)\end{array}$ & $\begin{array}{l}12.5-18 \mathrm{~kg} \\
28-40 \mathrm{lbs} .\end{array}$ & $\begin{array}{l}0.51(0.44-0.58) \mathrm{kg} / \text { week } \\
1(1-1.3) \mathrm{lbs} . / \text { week }\end{array}$ \\
\hline $\begin{array}{l}\text { Normal weight } \\
\left(18.5-24.9 \mathrm{~kg} / \mathrm{m}^{2}\right)\end{array}$ & $\begin{array}{l}11.5-16 \mathrm{~kg} \\
25-35 \mathrm{lbs}\end{array}$ & $\begin{array}{l}0.42(0.35-0.50) \mathrm{kg} / \text { week } \\
1(0.8-1) \mathrm{lbs} . / \text { week }\end{array}$ \\
\hline $\begin{array}{l}\text { Overweight } \\
\left(25.0-29.9 \mathrm{~kg} / \mathrm{m}^{2}\right)\end{array}$ & $\begin{array}{l}7-11.5 \mathrm{~kg} \\
15-25 \mathrm{lbs}\end{array}$ & $\begin{array}{l}0.28(0.23-0.33) \mathrm{kg} / \text { week } \\
0.6(0.5-0.7) \mathrm{lbs} . / \text { week }\end{array}$ \\
\hline $\begin{array}{l}\text { Obesity } \\
\left(\geq 30.0 \mathrm{~kg} / \mathrm{m}^{2}\right)\end{array}$ & $\begin{array}{l}5-9 \mathrm{~kg} \\
11-20 \mathrm{lbs}\end{array}$ & $\begin{array}{l}0.22(0.17-0.27) \mathrm{kg} / \text { week } \\
0.5(0.4-0.6) \mathrm{lbs} . / \text { week }\end{array}$ \\
\hline
\end{tabular}

Data from Institute of Medicine. Weight gain during pregnancy: reexamining the guidelines. Washington, DC: Institute of Medicine; 2009. 


\section{Table 6}

Gestational weight gain recommendations for twins

\begin{tabular}{|l|l|}
\hline Pre-pregnancy BMI & Total weight gain at term \\
\hline $\begin{array}{l}\text { Underweight } \\
\left(<18.5 \mathrm{~kg} / \mathrm{m}^{2}\right)\end{array}$ & $\begin{array}{l}17-25 \mathrm{~kg} \\
37-54 \mathrm{lbs} .\end{array}$ \\
\hline $\begin{array}{l}\text { Normal weight } \\
\left(18.5-24.9 \mathrm{~kg} / \mathrm{m}^{2}\right)\end{array}$ & $17-25 \mathrm{~kg}$ \\
$37-54 \mathrm{lbs}$. \\
\hline $\begin{array}{l}\text { Overweight } \\
\left(25.0-29.9 \mathrm{~kg} / \mathrm{m}^{2}\right)\end{array}$ & $14-23 \mathrm{~kg}$ \\
\hline $\begin{array}{l}\text { Obesity } \\
\left(\geq 30.0 \mathrm{~kg} / \mathrm{m}^{2}\right)\end{array}$ & $11-19 \mathrm{~kg}$. \\
\hline
\end{tabular}

Data from Institute of Medicine. Weight gain during pregnancy: reexamining the guidelines. Washington, DC: Institute of Medicine; 2009. 
Table 7

Risks of Obesity in Pregnancy

\begin{tabular}{|l|l|l|}
\hline During Pregnancy & During Labor \& Delivery & Postpartum complications \\
\hline Spontaneous miscarriage & Difficult fetal monitoring & Postpartum hemorrhage \\
\hline Birth defects & Cesarean delivery & Wound infection \\
\hline Limitations to ultrasound & $\begin{array}{l}\text { Decreased success of a vaginal } \\
\text { birth after cesarean delivery }\end{array}$ & Obesity in offspring \\
\hline Gestational diabetes & Difficult anesthesia & \\
\hline Hypertensive disease & & \\
\hline Stillbirth & & \\
\hline Fetal growth abnormalities & & \\
\hline
\end{tabular}


Table 8

Diagnostic testing along with prophylaxis and treatment of micro and macronutrient deficiencies in pregnancies after bariatric surgery

\begin{tabular}{|c|c|c|c|}
\hline Component & $\begin{array}{l}\text { Diagnostic testing } \\
\text { (serum) }\end{array}$ & Prophylaxis & $\begin{array}{l}\text { Treatment if } \\
\text { deficient }\end{array}$ \\
\hline Protein & $\begin{array}{l}\text { Serum albumin and } \\
\text { prealbumin }\end{array}$ & $60 \mathrm{~g}$ protein/day & Protein supplements \\
\hline Vitamin A & $\begin{array}{l}\text { Vitamin A, if clinically } \\
\text { indicated }\end{array}$ & $\begin{array}{l}4000 \mathrm{IU} / \text { day in } \\
\text { prenatal vitamin }\end{array}$ & $\begin{array}{l}\text { Vitamin A not to } \\
\text { exceed } 8000 \text { IU/day }\end{array}$ \\
\hline Vitamin D & $\begin{array}{l}\text { 25-hydroxy vitamin } \mathrm{D} \text {, } \\
\text { if clinically indicated }\end{array}$ & $\begin{array}{l}\text { 400-800 IU/day in } \\
\text { prenatal vitamin }\end{array}$ & $\begin{array}{l}\text { Calcitriol (vitamin D) } \\
1000 \text { IU/day }\end{array}$ \\
\hline Vitamin $\mathrm{K}$ & $\begin{array}{l}\text { Vitamin } K_{1} \text {, if clinically } \\
\text { indicated }\end{array}$ & $\begin{array}{l}\text { Not routinely } \\
\text { given }\end{array}$ & $\begin{array}{l}\text { Vitamin } \mathrm{K}_{1} 1 \mathrm{mg} / \text { day } \\
\text { Consult with } \\
\text { hematologist }\end{array}$ \\
\hline Folic acid & $\begin{array}{l}\text { Complete blood } \\
\text { count, red blood cell } \\
\text { folate }\end{array}$ & $\begin{array}{l}600-800 \mu \mathrm{g} / \mathrm{day} \text { in } \\
\text { prenatal vitamin }\end{array}$ & $\begin{array}{l}\text { Folic acid } 1000 \\
\mu \mathrm{g} / \text { day }\end{array}$ \\
\hline Vitamin $B_{12}$ & $\begin{array}{l}\text { Complete blood cell } \\
\text { count, Vitamin } B_{12}\end{array}$ & $\begin{array}{l}4 \mu \mathrm{g} / \mathrm{day} \text { in } \\
\text { prenatal vitamin }\end{array}$ & $\begin{array}{l}\text { Oral vitamin B12 } 350 \\
\mu \mathrm{g} / \text { day or } \\
\text { Intramuscular } \\
1000 \mu \mathrm{g} / \text { month } \\
\text { Consult with } \\
\text { hematologist }\end{array}$ \\
\hline Calcium & $\begin{array}{l}\text { Total and ionized } \\
\text { calcium }\end{array}$ & $\begin{array}{l}250 \mathrm{mg} / \text { day in } \\
\text { prenatal vitamin }\end{array}$ & $\begin{array}{l}\text { Calcium citrate } 1000 \\
\text { mg/day with Vitamin } \\
\text { D }\end{array}$ \\
\hline Iron & $\begin{array}{l}\text { Complete blood } \\
\text { count, iron, ferritin, } \\
\text { total iron binding } \\
\text { capacity }\end{array}$ & $\begin{array}{l}30 \mathrm{mg} / \text { day in } \\
\text { prenatal vitamin }\end{array}$ & $\begin{array}{l}\text { Ferrous sulfate } \\
325 \mathrm{mg} \text { twice-three } \\
\text { times/day with } \\
\text { vitamin C }\end{array}$ \\
\hline
\end{tabular}

Data from Mechanick JI, Youdim A, Jones DB, et al. Clinical practice guidelines for the perioperative nutritional, metabolic, and nonsurgical support of the bariatric surgery patient--2013 update: cosponsored by American Association of Clinical Endocrinologists, The Obesity Society, and American Society for Metabolic \& Bariatric Surgery. Obesity (Silver Spring) 2013;21(Suppl 1):S1-27; and American Academy of Pediatrics and the American College of Obstetricians and Gynecologists. Guidelines for perinatal care. 7th ed. Washington, DC: American Academy of Pediatrics and the American College of Obstetricians and Gynecologists; 2012. 